\title{
DOCUMENTS
}

\section{Statement by Mr. R.ALTANGEREL, State Secretary for Foreign Affairs of Mongolia in the General Debate of the 59TH Session of the United Nations General Assembly}

27 September 2004, New York

1. At the outset I wish to extend to you, Mr. President, my delegation's warmest congratulations on your unanimous election as President of the fiftyninth session of the United Nations General Assembly and pledge my delegation's full support in discharge of your duties. I am confident that under your able stewardship this session will successfully accomplish its mission.

2. The outgoing year has been a challenging time as the international community has been grappling with a host of formidable challenges including terrorist attacks, the threat of proliferation of weapons of mass destruction, violent internal conflicts, the surge of infectious diseases, natural disasters coupled with persisting poverty and hunger and humanitarian emergencies. Moreover, the war in Iraq, and its aftermath have entailed enduring imprint on the fabric of the international affairs in the Middle East and the world over. The bitter divisions that it had brought about on how to ensure our collective security against terror and the threat of proliferation of weapons of mass destruction - have posed a challenge and a test for the United Nations. It is gratifying to see that in these difficult times the world Organization has been able to regain its validity as "the indispensable common house of the entire human family".

3. To make the United Nations a more effective instrument for pursuing all the priorities identified in the Millennium Declaration the world leaders pledged their resolve to undertake a set of bold measures to reform the world Organization in order to enable it to adequately address the manifold challenges ahead. The task of reforming the United Nations will undoubtedly require devising truly innovative approaches and unfaltering commitment of member States. In this respect my delegation is eagerly awaiting the High-level Panel Report on Threats, Challenges and Change, and ensuing recommendations by the Secretary-General to be submitted to the General Assembly later this year.

4. In the meantime, my delegation highly commends the hard work and tireless efforts exerted by H.E. Mr. Julian R. Hunte, President of the 58th session of the General Assembly to revitalize the General Assembly. The two resolutions 
- 58/126 and 58/316-adopted under his skilful leadership proved to be by far the most far-reaching actions in more than a decade. Significant as they are, we should, nevertheless, aim higher and work with vigor to further reaffirm the central position of the General Assembly as the chief deliberative, policy-making and representative organ of the United Nations so that it can play that role more effectively.

5. On Security Council reform, I wish to join the previous speakers in reiterating that its composition has long ceased to reflect the current geopolitical realities. Mongolia reaffirms its support for a just and equitable enlargement of the Security Council by increasing the number of both permanent and nonpermanent seats while ensuring the representation of developing and developed countries. In this regard, my Government supports the legitimate aspirations of such countries like Japan, Germany and India which are willing and able to shoulder greater responsibility in pursuit of international peace, security and development. Permanent seats, in our view, should also be allocated to Latin America and Africa. Enlargement is not, however, a goal in itself - the expanded Security Council must be fully equipped to effectively react to the crises and conflicts of the new Millennium. It is also our view that the veto power ought to be thoroughly reviewed, and efforts should be exerted to turn the Council into a more democratic institution through enhancing its accountability and the transparency of its work.

6. There appears to be broad support emerging that the next year's HighLevel review of the implementation the Millennium Development Goals and the 60th Anniversary of the United Nations ought to produce bold decisions on our way onward so that the family of nations is able to attain the ambitious yet achievable goals set in the Millennium Declaration through display of genuine solidarity, shared responsibility and effective partnership.

7. As the Secretary-General has eloquently underscored last week in his statement to the General Assembly the need for upholding the rule of law in the whole spectrum of international and domestic politics, my delegation firmly believes that the rule of law and multilateralism represent the fundamental principles of international relations for the 21 st century. We must not falter or fail in pursuing them. The value of international law as the only viable framework of rules to govern the behavior and interaction among states, must never be measured in short-term perspectives or for near-sighted goals, neither should virtues of collective decision-making be contested. 
8. Violation of these principles even with the best of intentions is dangerous as one has to bear in mind that "the road to hell is paved with good intentions". Such actions would only bring about unforeseen and unintended effects that in the long run could be extremely harmful to the established international mechanisms and processes, and endanger the existing world order. This simple truth applies to every aspect of international life starting with the war on terror, maintaining peace and security to managing international trade and environmental protection. Indeed, any unlawful act would certainly have far greater repercussions that would most likely undermine the very reason of its execution.

9. The persistent instability in some regions and suffering of people from internal armed conflicts - are a setback from the commitment made by the world leaders in the Millennium Declaration to "spare no effort to free our peoples from the scourge of war, whether within or between States". Violence, hatred that spread across the Darfur region of Sudan is a tragic example.

10. In the Middle East, Mongolia notes with sadness the lack of progress on the path towards the peaceful resolution of the Israeli-Palestinian conflict. We urge both sides to exercise utmost restraint, and support the efforts of the Quartet in the implementation of the Roadmap.

11. Mongolia is also concerned with the security situation in Iraq. The end of occupation and the formal restoration of Iraqi sovereignty on 28 June 2004 were laudable achievements, yet the persisting climate of violence and insecurity threatens to undermine the efforts of the international community to bring peace, security and stability in the country. Mongolia wholeheartedly supports the political process based on UN Security Council resolutions 1483 and 1546, and the actions of the Interim Government towards convening a national conference, creation of an Interim Council, and holding of elections early next year.

12. The approaching presidential and parliamentary elections are important milestones for a new, democratic Afghanistan. Elections are a necessary prerequisite and a litmus test of democracy. The registration of voters numbering more than 10 million, significant portion of whom are women, clearly demonstrates the strong determination of the Afghan people to rebuild their country. Continued engagement of the international community remains crucial in keeping the peace and stability in Afghanistan and promoting the Bonn process. 
13. The Korean nuclear crisis and the resulting tensions on the Korean Peninsula cast dark clouds over the entire Northeast Asia. Being a Northeast Asian nation with a nuclear-weapon-free status, Mongolia stands for a nuclearweapon-free Korean Peninsula, and sees it as an important condition leading to the reconciliation of both Koreas, therefore, to peace and stability in the region. The continuation of the six-party talks with a view to coming to a negotiated solution is of vital importance to maintaining peace and stability on the Korean Peninsula and in the region as a whole.

14. Indeed, strengthening international peace and security, supporting practical disarmament measures in every possible way has been one of the main priorities of Mongolia's foreign policy. We firmly believe that disarmament efforts should equally focus on state-and-people-centered dimensions. The global landmine ban campaign and efforts to curb illicit trade in small arms and light weapons have immediate bearing on human security, social and economic development around the world.

15. As a strong advocate of WMD disarmament, and particularly nuclear disarmament, Mongolia believes that the full and effective implementation of the Treaty on Non-Proliferation of Nuclear Weapons on the part of both the nuclear and non-nuclear countries has a pivotal role in promoting international peace and nuclear security. In that context, Mongolia welcomes the UNSC resolution 1540 (2004) adopted unanimously under Chapter VII of the UN Charter as a meaningful step towards curbing the WMD proliferation, yet we also believe that a correspondingly significant step ought to be made in nuclear disarmament with the early entry into force and universalization of the Comprehensive-Test-Ban-Treaty as a first priority. This treaty, once in force, would greatly contribute to the prevention of horizontal and vertical proliferation of nuclear weapons, and the dangers posed by their possible acquisition by non-state actors.

16. Establishment of new and consolidation of existing nuclear-weaponfree-zones should remain high on the international agenda. My Government will continue its efforts towards institutionalizing its nuclear-weapon-free-status at the international level. Mongolia's internationally recognized and legallybinding nuclear-weapon-free-status could further contribute towards ensuring peace and stability in the region of Northeast Asia and beyond.

17. Global fight against terror remains high on the agenda of the international community. 9/11 heralded the start of an unprecedented global campaign drawing together countries, large and small, in their resolve to stand 
united to combat terrorism. And yet, despite the efforts of the international community, terrorism just like an ancient Lernaean Hydra seems to grow new heads for every one lost. The outgoing year was not an exception from that sad pattern, it was marked by continuous attacks against civilians - both Iraqi and foreign nationals, in Iraq; havoc wrecked on commuter trains in Madrid; and a string of attacks across the Russian Federation, the latest being the school massacre in Beslan - where children fell victim to an unprecedented atrocity beyond human comprehension. These events have underlined once again the need for an effective international anti-terrorist action. In the fight against terror the role of the United Nations is central in coordinating the actions of member States and providing them with technical and legislative support. Mongolia supports the efforts of the CTC aimed at its revitalization, and is looking forward to seeing the Counter-Terrorism Executive Directorate in operation. We also attach importance to speedy finalization of drafting international conventions on terrorism and nuclear terrorism.

18. No matter how pressing is the fight against terror; it should not overshadow other issues that impact daily lives of millions of people - from extreme poverty and hunger to environmental degradation and HIV/AIDS, to health and schooling. The complexity of the issues people are confronted with, the ever-increasing interdependence between countries and regions in the age of globalization, the intricate nexus existing between cause-and-effects of different phenomena require a holistic approach to the manifold challenges, both existing and emerging.

19. Growing development disparity between haves and have-nots, increasing poverty and unemployment in the developing world, in particular the least developed countries, debt burden and trade inequalities and further aggravation of such pressing issues remain our immediate cause of concern. We consider development as an effective root-cause treatment of social ills and in this context attach particular importance to the speedy implementation at the national, regional and international levels of the decisions and goals agreed by the Millennium Summit, Monterrey, Johannesburg and Rome. In this regard, my delegation welcomes the New York Declaration on the Action against Hunger and Poverty adopted on 20 September this year at the highest political level aimed at fostering our common fight to overcome poverty and increase financing for development.

20. Mongolia welcomes the adoption by the WTO members of the negotiating framework for the Doha trade round last July. It is of particular 
importance since the Doha Development Agenda provides vast opportunities for economic development and fair trade. We continue to stand for special and differential treatment of those developing countries, especially small and vulnerable economies, whose populations' livelihood considerably depends on granting full market access and low import tariffs on the part of their larger trading partners.

21. One year from now the world leaders will meet in Summit here to review the progress towards achieving the Millennium Development Goals. In preparation for this important event Mongolia has produced its first national report on the implementation of the MDGs and endeavors to consistently work towards their implementation in close collaboration with its development partners.

22. The world has witnessed in recent years the emergence of a new global commitment to democracy and good governance. According to the latest surveys, over 80 countries have attained substantial progress in their course to enhance democracy. Today, an unprecedented number of countries or 140 countries hold multiparty elections. A little over a year ago Mongolia hosted the 5th International Conference of New or Restored Democracies (ICNRD5) under the main theme of Democracy, Good Governance and Civil Society. At the end of their deliberations 119 participating countries adopted two major documents guided by a common aspiration to develop a just, humane, and accountable society that prioritizes elimination of poverty and inequality, and ensures sustainable human development.

23. As Chair of ICNRD5 Mongolia is now actively engaged in ensuring an effective and substantive follow-up to the conference both nationally and internationally. In this respect, my delegation wishes to commend the initiative put forward by President George W. Bush to establish a Democracy Fund at the United Nations to help countries to lay the foundations of democracy by instituting the rule of law and independent courts, a free press, political parties and trade unions. Such a fund, once operationalized, could greatly contribute to our common endeavors towards deepening democracy and good governance and developing an effective partnership with civil society towards implementing the MDGs.

24. This year Mongolia has held its 4th democratic parliamentary elections. As a result of the elections the two main political forces - the MotherlandDemocracy Coalition and the Mongolian People's Revolutionary Party - won almost equal number of seats in the Parliament. The two political forces have 
agreed to form a Grand Coalition Government on the basis of consensusbuilding which serves as a testimony to the fact that democratic principles and values have firmly taken root on Mongolian soil. I have no doubt, Mr. President, that the new Grand Coalition Government will pursue an action plan aimed at consolidating democracy and good governance, ensuring sustained economic growth, reducing poverty and unemployment as well as ensuring the continuity of Mongolia's open, multi-pillar and pro-active foreign policy.

\section{Joint Statement Between the United States of America and Mongolia}

Press Release by the White House, July 15, 2004

President Bagabandi and President Bush today declared a new era of cooperation and comprehensive partnership between their two democratic countries based on shared values and common strategic interests. They welcomed the progress in implementing the Joint Statement of January 31, 2004 and looked ahead to future consultations and collaboration. The two sides agreed to work towards maintaining regular consultations at all levels. They also expressed satisfaction that the relationship between their two countries continues to grow and strengthen. President Bagabandi's visit illustrates the important progress we have made in our bilateral relationship and in our mutual participation in the larger community of democracies.

The United States welcomed the recent free and fair elections in Mongolia as another manifestation of Mongolia's strong and abiding commitment to democracy.

President Bush expressed the United States'strong support for Mongolia's democratic and economic transition and reforms and welcomed Mongolia's progress toward becoming a mature and stable democracy and a private sectorled free market economy. He congratulated President Bagabandi and the Mongolian people for qualifying for eligibility for the Millennium Challenge Account, a new approach to achieving sustainable economic growth that rewards countries for past performance and provides incentives for continuing dynamic policy reforms. President Bush congratulated the Mongolian people on their commitment to democracy as expressed in their recent elections and noted confidence that the election process would be successfully completed in a free, fair and transparent manner consistent with Mongolia's constitution.

The two Presidents agreed that a democratic, secure, and prosperous Mongolia that promotes friendly relations with its neighbors and is an active 
participant in regional and international economic, political, and security forums is essential to ensuring peace and stability in Asia. The United States supports Mongolia's efforts to integrate itself into regional and international economic and financial structures.

President Bagabandi and President Bush also noted their common support for the permanent, thorough, and transparent dismantlement of nuclear programs on the Korean Peninsula. The United States acknowledges Mongolia's efforts to gain internationally recognized and legally binding nuclear weapon-free status to further enhance confidence-building measures in Northeast Asia.

President Bush welcomed Mongolia's commitment to combat international terrorism and applauded Mongolia's participation in the stabilization and reconstruction of Afghanistan and Iraq, including its peacekeeping commitment to the Multinational Force in Iraq. The United States and Mongolia agreed to continue working to advance Mongolia's contribution to international peacekeeping efforts. President Bush reaffirmed the U.S. willingness to continue bilateral programs of technical assistance consistent with Mongolia's longterm developmental goals. President Bagabandi expressed Mongolia's deep appreciation to the United States for its long-term support and economic assistance. The two Presidents agreed that the establishment of a free, democratic Iraq is important to democracy, peace and stability in the Middle East and the United Nations should play a leading role in the process.

The two Presidents agreed to actively promote bilateral trade and investment and noted signing of the United States-Mongolia Trade and Investment Framework Agreement during President Bagabandi's visit. The Presidents expressed the hope that this would lead in due course to a closer bilateral economic and trade relationship.

The two Presidents recognized that a U.S.-Mongolia relationship based on mutual respect and equitable partnership is in the national interest of both countries. They pledged to deepen and strengthen this important relationship and to work together to promote global freedom, peace, democracy and prosperity. 